Paulina POSPIESZNA

Adam Mickiewicz University in Poznań

DOI : $10.14746 /$ ps.2017.1.7

Gerald SCHNEIDER

University of Konstanz

\title{
DISPUTE OR MEDIATOR? THE SELECTION AND EFFECTIVENESS OF CONFLICT MANAGEMENT IN CIVIL WARS ${ }^{1}$
}

A discrepancy in international conflict management lies in the varying explanations offered by those trying to mediate a peaceful ending to a militarized conflict. When an attempt to reach a settlement fails, they contend that the intractable nature of the conflict prevented opposing parties from reaching an agreement. In the event of a successful outcome, conversely, the mediator statements often shift from blaming others to emphasizing their own strategies, skills, and trustworthiness. In September 1992, U.S. Secretary of State Lawrence Eagleburger for instance justified the passive stance of the Bush administration by claiming: "Until the Bosnians, Serbs and Croats decide to stop killing each other, there is nothing the outside world can do about it" (Danner, 1997). No such fatalism characterized the speech in which President Clinton described the pivotal role NATO and the U.S. had played in the conclusion of the Dayton Agreement, where he stated that, "Without us, the hard-won peace would be lost [...]" (Kuypers, 1997: 77).

The literature on mediation in militarized conflicts reflects these conflicting interpretations of the ability of mediators to successfully convince the warring parties to end their conflict. The structural perspective, which assesses the macro-level conditions under which mediation occurs, sees the conflict dynamics (Bercovitch, Langley, 1993; Kathman, 2011) and the nature of a specific rivalry (Goertz, Diehl, 1997) or regime (Dixon, 1993) as the main barrier to peace. A second approach, the individualist approach, stresses a mediator's identity, skills, and beliefs. In this viewpoint, it is especially the relationship between a mediator and the warring parties that allegedly foster the conclusion of an agreement (see e.g. Bercovitch, Schneider, 2000; Svensson, 2007).

\footnotetext{
1 Acknowledgements: The theoretical argument of this paper is partly based on a working paper the second author wrote with the late Jacob Bercovitch and Torsten Selck; both authors would like to dedicate this paper to the memory of their joint co-author. Previous versions of this paper have been presented at a workshop at the Center for the Study of Civil War, Peace Research Institute Oslo, Norway, the 2012 Annual Convention of the International Studies Association, San Diego, CA., and at the $8^{\text {th }}$ Pan - European Conference on International Relations the University of Warsaw, Poland 18-21 September, 2013. We would like to thank the audiences and in particular Håvard Hegre, as well as the editor and the reviewers for helpful comments. Financial support by the Fritz Thyssen Foundation to the first author is gratefully acknowledged, as well as by NCN/DFG to both authors within grant UMO-2014/15/G/HS5/04845 (Beethoven).
} 
This article tries to reconcile individual and structural explanations of conflict management occurrence and success. Drawing on the bargaining theory of war (Wagner, 2000, Powell, 2012), we develop a synthesis of these different theories and ask: Which conflict characteristics influence the success of mediation, and what sort of mediation strategy helps the warring parties to conclude a peace agreement?

Our argument conceives of mediation as a sequential, but integrated process (Wall, Stark, Standifer, 2001) in which at least three important decisions precede a possible peace agreement: 1) the selection of mediation as a way to resolve the conflict, 2) the choice of a particular conflict manager, and, lastly, 3) the decision by the mediating party to opt for a particular strategy. This means that we should start with an examination of mediation occurrence and strategy selection by the mediator (see also Beardsley, 2011: 45). We contend that, while the structural attributes of the conflict mainly influence the adaptation of mediation, individual features of the mediator affect the last two phases of the conflict management attempt: the choice of a particular conflict management strategy, and the final outcome. Our adaptation of the bargaining theory of war (Wagner, 2000; Powell, 2012) suggests that warring parties carefully select a mediator who will only be able to use decisive strategies if they allow the conflict manager to do so or if they underestimate its ability to change the status quo. The first perspective suggests that the usage of mediation strategy is determined by the conflict and the evolving balance of power between the disputants. Individual strategies can in line with the second viewpoint only become effective if the disputants underestimate the mutually chosen or accepted mediator. We henceforth expect that what we call decisive strategies make a difference when the warring parties did not expect such an intrusion or when they saw less interventionist mediation fail in previous attempts by outside parties to bring peace to a violent conflict. Decisive strategies comprise in other words what Bercovitch (1991) "procedural" and "directive" measures. They move beyond the communication facilitation that less powerful communication facilitators provide or that are tried out in a first conflict management attempt.

The empirical evaluation of our synthesizing argument of the structural and individual perspectives is based on the Civil War Mediation (CWM) dataset (DeRouen et al., 2011). This source exclusively focuses on civil war mediation in the period from 1945 to 2004, and provides detailed information on mediated and non-mediated conflicts. Heckman probit regressions show that mediated conflicts are not a random sample of all civil wars examined, and that especially intensive conflicts and conflicts with a "hurting stalemate" are more likely to experience this sort of voluntary conflict management. However, the outcome of mediations is not only determined by the structure of the conflict alone. The analysis reveals that decisive strategies and multilateral mediations are more effective even if we control for the selection effects.

The data also shows that mediations initiated by a third party are more likely to fail than conflict management proposals by the belligerents. This finding indicates that the hands of mediators are often tied and that their decisive strategies only make a difference when the forward-looking warring parties did not expect the mediator to act effectively. Directive strategies are effective in leading to the conclusion of peace agreements not only because of their virtues but also because they can build on previ- 
ous mediation efforts. With respect to other mediation attributes, such as the identity of the mediator and the location (territory) where the mediation takes place, we find that they do not systematically increase the chance of peace process to be concluded in form of the agreement.

\section{UNDERSTANING THE PHASES OF MEDIATION}

Most militarized disputes since 1945 have experienced some type of conflict management, with mediation and bilateral negotiations being the most popular mechanisms (Bercovitch, Fretter, 2007: 149). The particular mechanism this article studies is mediation, which Bercovitch, Anagnoson and Wille (1991: 8) define as "[...] a process of conflict management where disputants seek the assistance of, or accept an offer of help from, an individual, group, state or organization to settle their conflict or resolve their differences without resorting to physical force or invoking the authority of the law". ${ }^{2}$

Mediation therefore represents a non-violent third party intervention, and encompasses a wide range of strategies and tactics that are all aimed at resolving the conflict at hand (Terris, Maoz, 2005: 563-566; Beber, 2012: 5; Regan, Aydin, 2006: 739-740). The third party can choose the sites for the mediation, chair the meetings, convey proposals and directly influence the conflict management attempt through persuasive- and pressure tactics to entice the warring parties to reach an agreement.

Bercovitch et al. (1991) developed a trichotomy that categorizes mediation strategies according to their strength into (1) directive, (2) procedural, and (3) communication facilitation strategies, with the first two considered to be more decisive. A directive strategy is the most powerful form of intervention, as the third party can shape the content and nature of a final outcome either by promising support or by threatening actors with diplomatic sanctions or other coercive measures. Conversely, a procedural strategy enables the mediator to control the conflict management environment. Lastly, communication facilitation encompasses relatively passive tactics that range from providing information to organizing talks between belligerents. Interventions by the United Nations, such as in Cambodia, Croatia, Georgia, Indonesia, Morocco, Mozambique, and Tajikistan, often rely on a procedural strategy rather than communication facilitation. On the contrary, multilateral mediation teams often take a more timid stance; communication facilitation strategies were for instance used by the Organization of the Islamic Conference (OIC) and a group of state mediators (Somalia, Senegal, Saudi Arabia, Indonesia) during the conflicts in the Philippines with MNLF/MILF in the 1970s and 1990s.

Drawing on the categorization by Bercovitch et al. (1991), we argue that such decisive strategies can make a difference even if we account for the inability of some conflict managers to rely on such forceful tactics. Directive strategies are effective in leading to the conclusion of peace agreements, no only because of what they entail. As we will detail below, they can tip the scale if their usage was not expected or if

2 The definition is widely acknowledged and commonly used in the literature (see DeRouen, Bercovitch, Pospieszna, 2011: 664 or Beardsley, 2008: 724). 
they build on previous mediation attempts. We join in this way an intensive scholarly debate about the factors that render mediation successful. ${ }^{3}$

Kleiboer (1996: 360) speaks of a quest for a "golden formula", showing that the instruments, tactics and strategies chosen by the mediator play a particularly prominent role among these potential drivers of mediation success. ${ }^{4}$ Despite this optimistic assessment, most studies that link conflict management success to mediation and mediator characteristics have come up with mixed results.

We contend in line with a growing literature that the success of mediation attempts can only be meaningfully assessed if we consider that mediations do not occur randomly (Beber, 2012; Beardsley, 2011: 45; Clayton, 2015; Gartner, 2011; Svensson, 2007), and that not all mediators have the same chance to rely on forceful mediation strategies (Bercovitch, Schneider, 2000). For example, only resourceful mediators can credibly rely on "settlement oriented" mediation, which requires considerable manipulations by the conflict manager, and which is therefore also called "directive" or "heavy." According to Bercovitch (2011: 48), a mediator "may achieve this by using a combination of sticks and carrots, provision of incentives, offering rewards and punishments, issuing of ultimatums, and introduction of new proposals." While this may drive promising results, some mediators cannot intervene in a determined fashion, meaning they must rely only on communication to facilitate the exchanges between the warring parties.

To understand the choice of mediation strategies and their impact, it is necessary to analyze why mediation occurs, and why certain mediators are chosen. A fruitful, yet pessimistic, starting point to do so is the neo-Clausewitzian bargaining theory of war. This approach, pioneered by Wagner (2000), expects that negotiations become more likely in a situation of a stalemate on the battlefield. As Powell (2012: 627) for instance writes, "the factions negotiate agreements and avoid fighting when the distribution of power is either completely stable or slowly changing." Barring any misperception of the other side's power, this perspective attributes peaceful ends to the power distribution of the contending forces. This means a mediation attempt will not systematically affect the chance of peace, irrespective of how skillful and determined a mediator may be.

If the warring parties are insincere in their mediation attempt and use the conflict management solely to buy time before returning to the fighting, the effort of a mediator remains equally inconsequential. As mediation is a voluntary process, no warring party will accept a mediator who is able to affect the power distribution in a negative way. In this perspective, effective mediation only becomes possible if at least one of the fighting groups underestimates the power of the mediator. This rational expectation perspective that mediation can only make a difference in a situation of uncertainty

${ }^{3}$ In this study we focus on short-term mediation success, which is typically defined through the conclusion of a peace treaty (Beardsely et al., 2006; Frazier, Dixon, 2006; Regan, Aydin, 2006; Walter, 2002; Wilkenfeld et al., 2003; Svensson, 2007; Rauchhaus, 2006). A long-term success, by contrast, is only possible if the parties to this formal or informal mediated agreement do not take up arms over an extended period.

${ }^{4}$ The literature on this topic includes Bercovitch and Gartner (2009), Wilkenfeld et al. (2003), Maoz and Terris (2009), Beardsley et al. (2006), Svensson (2007). 
about the determination of the mediator is similar to the classic third party intervener paradox by Rubin (1980: 389), which finds that "[...] it is precisely when third-party intervention is likely to be needed most - when conflict is intense - that the anticipation of intervention may prove least helpful [...]."

Despite this gloomy outlook, successful mediators nevertheless insist that their strategies made the crucial difference in turning a seemingly hopeless conflict management attempt into a success. Yet, decisive strategies are only used by mediators who can muster sufficient power to "convince" recalcitrant belligerents. For instance, IGOs are often only able to act as neutral, but nevertheless forceless go-betweens in their mediation attempts. According to Bercovitch (1992), regional and intergovernmental organizations' primary resources are their expertise and legitimacy. Lacking the resources to encourage or discourage disruptive behavior, IGOs should naturally resort to communicative or procedural rather than directive strategies (see also Amoo, Zartman, 1992; Jonah, 1992). Similarly, Svensson (2009) finds that the UN is more restrictive with its promises, and is generally perceived as a more credible guarantor by disputants, which implies that it is more likely to use procedural or, to a lesser extent, communicative, rather than directive, strategies.

However, no scholarly consensus exists regarding which mediation strategy presumably works best. Zartman and Toub (1985), and Quinn et al. (2013) demonstrate empirically that "manipulative" conflict management can make a difference, while formal models by Kydd (2003) and Rauchhaus (2006) outline the conditions under which even information provision to the disputants can lead to peaceful outcomes. Bercovitch and Houston (1993: 304) argue that directive strategies "help parties to save face, equalize power imbalances, and generally move the disputants toward a more cooperative orientation," and Smith and Stam (2003: 128) further add that mediators cannot succeed by only acting as information providers.

Students of conflict management frequently assert that setting positive and negative incentives by a third party transforms the conflict dynamics. Beardsley et al. (2006: 81-83) emphasize, however, that facilitative strategies are the best possible answer to commitment problems and post-crisis tensions, while more intrusive forms of mediation seem to be redundant in such context. Beardsley (2011: 41) shows that manipulative mediation - what he calls "heavy-handed mediation" or "mediation with leverage" - may create temporary incentives for combatants to make peace, but resorting to conflictive strategies will become attractive again once those artificial incentives are removed.

In the following section, we will address the controversy over the effectiveness of decisive strategies in conflict management. To do so, we advance the rational expectations framework outlined above that unites the structural and actor-centric perspective. We contend that warring parties select a mediator based on how conducive its anticipated conflict management strategy is to their own interest. If they are seriously seeking peace, they will strive for a consensus in finding a mediator who can help them finding an acceptable compromise. If, on the other hand, warring parties are simply trying to buy time, they will propose a weak conflict manager whose mission is bound to fail. The strategies adopted by a third party make in this perspective a difference if the belligerents underestimate the determination of a mediator. 


\section{STRUCTURAL FACTORS}

The neo-Clausewitzian literature on war as a bargaining process suggests that the decision of warring parties to request and accept the involvement of a third party depends on the chance to agree on a settlement that is more attractive than the payoff associated with continued fighting. The realized and anticipated costs of war are one of the key parameter in this decision making calculus. A considerable number of studies has highlighted that he number of casualties incurred can severely affect the actor's willingness to engage in mediated talks and settling the conflict peacefully (e.g. Mason, Fett, 1996: 551). If there is a substantial loss to casualties, we could expect that the warring parties are more likely to initiate or accept mediation as a conflict management tool as they gradually realize that the losses are too large to continue fighting (e.g. Young, 1967).

However, Burton (1969) argues exactly the opposite; according to him, the higher the costs borne by each party, the more polarized their positions will be, rendering them more reluctant towards conflict management and mediation. Despite this, a growing blood trail serves to weaken leadership support from below. We therefore expect that warring parties are more likely to request and accept mediation when a conflict becomes more severe.

Another facet of costliness is war duration and conflict fatigue. Some analyses show that the chance of mediation increases with the length of a violent conflict (Greig, Diehl, 2006; Bercovitch, Jackson, 2001; Svensson, 2008). War-weariness may obviate the futility of military means, and therefore render combatants more willing to negotiate (Zartman, 1989). Empirical studies show that territorial disputes trigger more often political violence, and that the conflicts which erupt over these issues, also last longer. ${ }^{5}$ According to DeRouen et al. (2011), territorial wars are more likely to be mediated than governmental wars. However, such mediation attempts less often result in peace agreements. Furthermore, if an agreement can be made despite such constraints, these treaties additionally face a high risk of failure. ${ }^{6}$

Based on this reasoning, we contend that the intensity of a conflict also influences the chance that third parties employ decisive strategies. Bercovitch and Houston (2000) demonstrate that a mediator's choice of strategy largely depends on the conflict and the needs of the parties involved. A similar logic applies to the effects of conflict intensity on the effectiveness of a mediation attempt. Acknowledging the possibility of selection effects, Bercovitch and Gartner (2006) establish that directive strategies will more likely be successful in in a low-intensity conflict than conflict-management that emphasizes communication.

Böhmelt (2010: 173) statistically takes the selection into account and shows that the relationship between the intensity of mediation in conflicts and its success is curvilinear: "[ $[.$.$] both low and high intensity disputes are less likely to see interventions$

${ }^{5}$ By definition governmental conflicts are fought over the control and orientation of the government, while territorial conflicts are secessionist or autonomy-seeking wars (see http://www.pcr.uu.se/ research/ucdp/definitions/).

${ }^{6}$ See for instance the studies by: Balch-Lindsay and Enterline, 2000; DeRouen, Bercovitch, 2008; DeRouen et al., 2011. 
and effective outcomes." Nevertheless, while mediation tends to work best before conflicts become very intense, conflicts must become heated enough for the warring parties to feel a need to find a resolution. Therefore, we advance the hypothesis that conflict intensity renders active mediation strategies more likely.

H1: High-intensity conflicts are more likely to encounter mediation as a conflict management instrument.

In addition to the aforementioned factors, the power of a country experiencing a civil war also influences its willingness to accept international mediators (Bercovitch, Schneider, 2000; Svensson, 2007). The power to withhold may stem from a membership in a military alliance. While pooling resources and decision-making capacities decreases the discretion of the national government, it can count on the support of fellow members in its resistance to the involvement of a third party. Leaders of powerful countries might equally be less willing to request external help and to accept external mediation as an international conflict management tool since they feel more capable of handling the conflict unilaterally. Thus, we argue that leaders of populous and internationally connected states are more likely to withstand offers to mediate in internal conflicts.

\section{H2: More powerful war-torn countries are less likely to experience mediation.}

Once warring parties agree on mediation and the possibly selected mediator accepts an offer to intervene, the conflict management officially starts. Some scholars argue that mediator characteristics are a major factor of effective mediation (e.g. Young, 1968). Below, we will examine the attributes of mediators that may affect the choice of strategy and the success of the conflict management attempt.

\section{MEDIATION CHARACTERISTICS AND THE SEQUENCING OF MEDIATION STRATEGIES}

Our overarching theoretical argument suggests that both the conflict attributes and the power and strategies of the conflict manager matter in determining the outcome of mediation. Since potential mediators can reject an invitation to manage a conflict, they more likely accept if they feel they can derive some benefit from their intervention (Bercovitch, Schneider, 2000; Greig, Regan, 2008: 762-765; Terris, Maoz, 2005: 567-568). Regardless of whether a mediator is a state representative, IGO delegate or private individual, a main benefit of mediation success is a boost in prestige. Additionally, state mediators might see a conflict management attempt as a means to nurture an existing alliance, to gain strategic influence, or to improve economic relations (Greig, Regan, 2008: 762-763).

Conversely, international organizations are often involved, as Touval (1994: 46; see also Bercovitch, Gartner, 2006) argues, in "orphaned conflicts," which are intense and difficult to resolve. Engaging into intractable wars is less attractive for state leaders, as prospective benefits are less likely. IGOs are less selective, as their mandates often explicitly include their engagement as conflict managers. For example, the UN has an 
obligation to act as a global conflict manager. ${ }^{7}$ Despite this, international organization might also possess better resources for dealing with such disputes.

While powerful states and IGOs are the most frequently appointed as conflict managers (Bercovitch, Schneider, 2000: 162), it remains unresolved which type of mediator is more successful. Some scholars find that the disputants favor mediation by hegemonic states rather than mediation by international organizations (Ibid.: 153), and that efforts by a powerful mediator are more successful. Svensson (2007: 229) contends that, although all types of mediators have a positive effect in terms of reaching agreements, powerful mediators outperform "pure mediators," which include representatives of IGOs, NGOs, regional organizations, small and distant states, as well as private individuals. On the other hand, Slim (1992) argues that less powerful mediators, such as Algeria, Switzerland, and Austria, can profit from their strategic weakness. According to him, relatively weak states can be successful in mediation since they cannot credibly threaten either of the adversaries with the possibility of punitive action (Frazier, Dixon, 2006: 390-391). Bercovitch and DeRouen (2005: 108) support this result and argue that superpower mediation decreases the chance for success.

There are also mixed results concerning the involvement of international organizations. Bercovitch and Gartner (2006: 356) find that international organizations are better able to deal with highly intense and intractable conflict, as they have more resources at their disposal. Additionally, DeRouen (2003: 251-260) finds that the UN mediates ethnic civil conflicts quite successfully. Frazier and Dixon (2006: 401) suggest that international government organizations (IGOs) are best at securing a negotiated settlement, since multilateral actors not only provide legitimacy but are also more likely to create an environment conducive to conflict resolution. Conversely, Touval (1994: 53-54) argues that international organizations are not destined to mediate. Using the United Nations (UN) as an example, she points to the lack of real power and leverage, as well as the membership structure of international organizations in making a coherent mediation strategy less likely. She furthermore finds that the slow administrative machinery of organizations makes them inflexible. Other authors like Bercovitch and DeRouen (2005: 108), Bercovitch and Houston (1993: 317; 1996: 27) or Doyle and Sambanis (2000: 791) similarly paint a gloomy picture of UN-led mediation attempts. They nevertheless trace the UN's poor record to unpromising selection effects, finding that the organization is mostly mediating conflicts that are already very hard to resolve. Trying to end seemingly intractable wars is less attractive for state leaders as the chance to increase their own popularity through successful conflict management is rather dim in comparison to "easy" conflict. While international organization might "inherit" such conflicts from unsuccessful state mediators, they might also possess better resources for dealing with such disputes.

${ }^{7}$ However, we may expect regional organizations to behave differently. They are attached to a specific region and may have "vested interests" in certain conflicts, which might bias their activities (Elgstroem et al., 2003: 23). Further, they may act in order to prevent a conflict from destabilizing a region (Greig, Regan, 2008: 764). Gartner (2011), studying the duration of peace agreements mediated by regional organizations, nevertheless argues that they are mainly selected as mediators in civil wars that are highly intractable. 
We believe that these contradictory results are largely due to the neglect of recognizing the endogenous nature of the strategy choice of the mediator. Before warring parties agree to given mediation terms, they must first gauge which mediation tactics are in their interest, and decide on the profile of the mediator. If they do not want the mediation to succeed, they are more likely to agree on a conflict manager who is less likely to resort to powerful conflict management strategies. Nevertheless, the warring parties cannot perfectly anticipate the behavior of the mediator. This means that conflict managers who surprisingly opt for a decisive strategy might be more successful than those who intervene less intrusively.

\section{H3: If a mediator or a team of mediators employs a decisive strategy, the chance of mediation success increases.}

Once after accepting a mandate, one crucial task any careful mediator cannot avoid is the study of how the violence evolved and why possible previous conflict managements have failed. We expect that one of the key lessons will be the avoidance of inconclusive strategies (Bercovitch, DeRouen, 2004; DeRouen, Bercovtich, Pospieszna, 2011). Clearly, the history of the previous events may deter mediator from offering conflict managements as well as the warring states from inviting new mediations. However, once mediation takes place after unsuccessful mediations, it is more likely that a decisive strategy will be used. In other words, if mediation attempts took place in the past and they failed, there is reason to believe that this experience may have taught the mediators to adopt a more decisive strategy. The agreement of the conflict parties to engage into a new mediation attempt also signals that they might be really interested in a peaceful resolution of the conflict. Finally, the more mediation attempts have failed, the more "ripe" a conflict is for peaceful resolution. Böhmelt (2015) finds empirical evidence for such turning points and also shows that mediation success increases if the same mediators intervene over the course of a dispute.

\section{H4: Previous mediation attempts increase the chance of decisive mediation strategies and of a successful outcome.}

The rationalist theory of bargaining in wars can be adapted to mediations which are voluntary and where the disputants have a complete freedom to act. However, mediations can often not completely be separated from interventions in which the conflict managers self-appoint themselves to the pacifying task. One crucial characteristic of the selection process is therefore whether the belligerents approached the mediator themselves, or whether a mediator took the initiative. Our analysis differentiates accordingly who initiates the mediation attempt. We believe that, if one or both warring parties initiate a mediation attempt, they demonstrate the willingness for conflict resolution, thus making mediation more likely successful. In exploring the link between mediation initiation and the effectiveness of conflict management, Greig (2001: 699) argues in this vein that mediation initiated by one of the rivals is more likely to be successful. "Even if this expectation develops within only one rival, the perception of a way out may foster greater flexibility in negotiations-improving the prospects for mediation success."

As decisive strategies might risk to benefit one side more than the other, mediations initiated by the disputants should largely rely on communicative strategies. The 
warring parties mandate third party intervention mainly for the provision of information. This implies that mediator-initiated conflict management is more likely to resort to decisive strategies. Yet, as the disputants often perceive outside interventions as coercion and are not "ready" for sincerely negotiating a peace agreement, they are more likely to resist conflict resolution proposals if they are made by an external source. The failed mediations of India in 1985 and 1986 in the civil war in neighboring Sri Lanka illustrate this tendency. We therefore argue that outside parties who initiated the mediation themselves are more likely to muster decisive strategies, but that this forcefulness does not translate into an increased chance of peace. We expect that mainly mediators who act on behalf of a state can muster the resources needed to employ directive strategies.

H5: States as initiators of a conflict management attempt are more likely to rely on decisive strategies, but face an increased risk of seeing their attempt ending in failure.

In directive strategies, the mediator must either promise a reward in exchange for the acceptance of a certain proposal, or threaten with punishments in case that they remain intransigent. Procedural strategies in return require considerable agenda setting possibilities. Not all mediators have the means to credibly commit to a potential agreement that involves such enhanced leverage. In this scenario, states are in a better position than international organizations, as they can unilaterally determine the extent of inducements and sanctions they want to offer. It thus seems reasonable to expect that states are more likely to use directive strategies during mediation than other conflict managers. Of course, rational warring parties will anticipate that states have a better chance to employ more decisive strategies than IGOs or independent mediators. This means that state-led mediations will not necessarily be more effective than the ones conducted by other mediators such as the United Nations or other international governmental organizations.

A bias of a mediator towards one of the conflict parties can hamper the pacifying role of the mediator as it will not necessarily provide accurate information to the disputants (Rauchhaus, 2006). Yet, mediators can only be biased if they have sufficient leverage to set positive and negative incentives. Less powerful mediators tend therefore to be more neutral than more resourceful ones. Smaller powers, however, increase their influence on the disputants through teaming up with another mediator. We therefore expect that multilateral teams will be more successful in their attempts to bring peace to a violent conflict, but that they are not necessarily able to pull off decisive strategies.

H6: Multilateral interventions are more likely to lead to mediation success, although they are less likely to rely on decisive strategies.

States are in a better position than international organizations as they can decide alone about the incentives they want to offer. It thus seems reasonable to expect that states are more likely to use directive strategy during mediation than other conflict managers. As our theory suggests, rational warring parties will anticipate that states have a better chance to employ more directive strategies than IGOs or independent 
mediators. The belligerents can, however, not anticipate whether the mediator entices them to negotiate their plight on its own territory. Such a transfer away from the conflict zone puts pressure, often under the limelight of international media, on the disputants to give in to a negotiated settlement.

The case study literature strongly suggests in this vein that it matters where mediation occurs. In examining the case of Camp David, Bercovitch (2011: 121) contends that neutral settings where neither party has "any potential for territorial and psychological dominance" come with clear advantages over other locations (Ibid.). In an earlier study, he also finds that mediation attempts that take place in a peaceful environment can bring better results rather than attempts taking place in conflict territory (Bercovitch, 1996). Of course, a neutral territory is not neutral in the sense that mediators are completely unbiased to the belligerents in the civil war. Yet, meeting in another country legitimized in an internal conflict the rebel forces which are often do not enjoy the same legitimacy as the government. Given this, we argue that mediation on the third-party territory is more likely to end with success.

\section{H7: Mediation attempts that take place on the third party territory have an increased chance to be successful.}

We theorize that the occurrence of mediation, the selection of a decisive strategy and the final outcome of the conflict management attempt are intertwined processes that should be studied together. In doing so, we acknowledge that mediation cases are neither a random sample of all militarized disputes nor of all militarized disputes that experience some sort of conflict management (Bercovitch, Gartner, 2009). If we were exclusively looking at mediation success, we would either under- or overestimate the relative success of this conflict management technique.

\section{RESEARCH DESIGN}

This study examines the success of mediation attempts as a stepwise process. As the theoretical framework stresses the importance of selection effects, we run Heckman probit models to explain the choice of mediation strategies and mediation success. The selection stage of the Heckman model considers whether or not a conflict experiences a conflict management or not. Heckman models are the most common approach to deal with selection issues, and have also been included in several studies of conflict management (Böhmelt, 2010). ${ }^{8}$ Terris and Maoz (2005) moreover address the selection problem by using several techniques to show that the "versatility" of a conflict affects the probability that it will experience mediation. The Heckman probit approach that we use to account for strategic censoring in our models (Heckman, 1974, 1976, 1979; Van de Ven, van Praag, 1981) is built on a number of assumptions, among them the exclusion restriction. We need, in accordance with this requirement, to include some regressors in the selection equation that do not make part of the second-stage estima-

${ }^{8}$ Other applications include examinations of the effectiveness of sanctions (Nooruddin, 2002), the likelihood of negotiated dispute settlement (Dixon, Senese, 2002) and the escalation of disputes (Kinsella, Russett, 2002). 
tion. We will use in line with our theoretical framework all the conflict characteristics for this purpose. At the selection stage, we also control for the impact of democracy, war recurrence, the internationalization of the civil war, and alliance membership on the choice of mediation.

Dixon's $(1994,1993)$ finds that democracies are more likely to agree on a peaceful resolution of interstate conflict and therein accept an outside management. This suggests that political openness might also make these states more amenable to a peaceful resolution of the conflict. Similarly, mediators may be more likely to intervene if the state which has succumbed to a civil conflict is sufficiently democratic (Wallenstein et al., 2009). Yet, civil wars in democracies represent cases that are particularly difficult to resolve, often pitting presidents with a clear electoral mandate against rebel organizations that represent large ethnic groups (Schneider, Wiesehomeier, 2008). This suggests that the relationship between democracy and mediation is theoretically inconclusive. It is therefore not surprising that DeRouen et al. (2011) have found no evidence that regime type, measured here by the Polity score at the end of the civil war episode plays a role in mediation.

Internationalization of war measures whether another country intervened militarily (coded as 1) or not. We can expect that military presence of the third country may both enhance the prospects of peace and encourage meditation. Following DeRouen et al. (2011), we expect that the number of previous conflicts is related to chance for mediation. Recurrence is coded 1 if at least one internal war terminated before, 0 otherwise. Membership of a conflict country in a military alliance should also reduce the chance of mediation. The analysis therefore controls with a dummy variable whether a state was a member of Military Alliance (such as NATO, Warsaw Pact, SCO, Arab League, and CSTO during the conflict).

We will use the Civil War Mediation (CWM) Dataset compiled by DeRouen et al. (2011), which draws on the UCDP Conflict Termination Dataset. ${ }^{9}$ The CWM dataset was published in two versions, one containing 319 civil war episodes and one containing 460 civil war mediation events (by states and other actors). As this analysis needs both specific information on the mediated events and information regarding the civil conflicts, the two versions of the CWM dataset were merged. The time period studied ranges from 1945 to 2004.

The dataset lists the names of mediators. We decided to group them into singleparty mediations and multiparty mediations (Table 1). We also distinguish whether the former category was led by a state or by an IGO. The descriptive evidence also shows that mediations by states which are powerful through their permanent membership in the United Nations Security Council occur quite frequently. Further, the frequencies in which states or international organizations act as mediators are quite balanced. The UN plays a dominant position among international organizations (almost $20 \%$ of all single mediation attempts assigned to IGOs are led by the UN). Three similar categories are built for the analysis of multiparty mediations. We distinguish between UN-led teams, multilateral initiatives uniting representatives of nation states and a mixed lineup of IGO and state mediators.

9 The UCDP/PRIO uses a threshold of at least 25 battle-related deaths to define civil war episode. 
Similarly, we can identify better multiparty mediations by specifying whether mediation was led by a group of different actors (e.g. different states, IGOs), or a group led by the UN, or by the group of different states.

Table 1

Mediation Occurrence by Mediator's Identity

\begin{tabular}{|c|c|c|c|}
\hline & Freq. & Percent & Cum. \\
\hline \multicolumn{4}{|l|}{ Single party mediation } \\
\hline Individual & 15 & $4.70 \%$ & $4.70 \%$ \\
\hline IGOs & 155 & & \\
\hline United Nations & 62 & $19.44 \%$ & $24.14 \%$ \\
\hline Other IGOs & 93 & $29.15 \%$ & $53.29 \%$ \\
\hline States & 149 & & \\
\hline UN Security Council permanent members & 45 & $14.11 \%$ & $67.40 \%$ \\
\hline Other states & 104 & $32.60 \%$ & $100.00 \%$ \\
\hline Total & 319 & $100.00 \%$ & \\
\hline \multicolumn{4}{|l|}{ Multiparty mediation } \\
\hline UN-led & 33 & $25.38 \%$ & $25.38 \%$ \\
\hline Group of states & 59 & $45.38 \%$ & $70.77 \%$ \\
\hline Mixed mediation & 38 & & \\
\hline UN+EU mediation & 14 & $10.77 \%$ & $81.54 \%$ \\
\hline Other mixed mediation & 24 & $18.46 \%$ & $100.00 \%$ \\
\hline Total & 130 & $100.00 \%$ & \\
\hline
\end{tabular}

Source: Own calculations based on data collected.

The first dependent variable is whether mediation has been chosen as a conflict management strategy or not. Mediation Occurrence is 1 if the conflict parties agreed on mediation, and 0 if they did not. Note that the zero category includes decisions in favor of other conflict management strategies as well as those few disputes that did not experience any conflict management at all.

To test our hypotheses on the choice of mediation strategies, the dataset distinguishes, as indicated, three different types: Directive Strategy, Communication Facilitation Strategy, and Procedural Strategy. Since procedural and directive strategies are more active than the facilitation of communication, we will collapse them into the category Decisive Mediation Strategy with 1 standing for this choice and 0 for the absence of a forceful strategy.

In order to unravel the impact of mediator type and strategies on the effectiveness of the conflict management effort, we transform these individual categories into dummy variables. We coded Mediation Success in line with most research evaluating the effectiveness of short-term mediation, as 1 if a mediation attempt resulted in a partial settlement, full or process agreement, and as 0 otherwise.

The independent variables that account for the possible influence of the conflict structure on the steps of mediation include two indicators of conflict intensity: the log of the total Battle Deaths until the conflict managements sets in, and the log of War Duration, which stands for the length in days since the outbreak of the war. All data are from CWM mediation dataset. Some studies have found that the type of conflict the warring parties are fighting matters - territorial wars are more likely to be mediated but at the same time are less likely to end with peace agreements than governmental 
wars. Yet, territorial wars tend to be longer, more intractable and to be more frequently recurring than militarized conflicts over government control. As we measure conflict intensity, our analysis will not control for the type of incompatibility. It is therefore in our view sufficient to examine the impact of conflict intensity on mediation.

Other structural factors relate to the characteristics of a conflict country. We used World Development Indicators to collect data for economic development, which is measured by the logged Gross Domestic Product per capita (GDP per capita) in 2004, and for a country size measured by Population in 2004.

The independent variables that describe mediation attempts were taken from the Civil War Mediation dataset. From the variable in the dataset that refers to the location of mediation we created the dummy variable: Third-party Territory. We will also evaluate the result of mediation attempt solely initiated by mediator and thus created three dummy variables, a general one Mediator-initiated, to indicate that the incentive to mediate came from the mediator rather than from the warring parties. However, we also distinguished to see whether it matters for the mediation success who initiates, therefore we created another two dummies: State initiated mediation, if a state representative offered mediation as a conflict resolution tool, or IGO initiated mediation, when an organization stepped in to offer mediation. The variables are based on data in CWM dataset.

Finally, we introduce a variable that will allow us to account at least to some extent for the effect of previous mediations on the strategy choice and the success of the conflict management effort: Previous Mediation (1 if one or two mediation attempts occurred previously and 0 if no mediation was observed).

\section{EMPIRICAL ANALYSIS}

This article conceives of mediation as a stepwise process in which belligerents accept an offer by a third party to end their dispute or chose mediation themselves as a means to solve a conflict. Once this crucial initial selection has been made, mediators rely on different strategies in order to boost the chance of their efforts ending successfully. Our testing strategy reflects this procedural nature of conflict management. We first examine jointly the criteria under which warring parties decide in favor of mediation and the conditions under which the chosen conflict managers opt for a decisive strategy. Second, we study the covariates of mediation success by controlling for the tendency of certain conflicts to "self-select" themselves into this form of conflict management. Our statistical tests are Heckman probit models.

Table 2 presents the conditions under which belligerents accept mediation as a possible conflict resolution mechanism and, given this decision, what strategies the conflict managers opted for. The standard errors are adjusted for clustering on dyads between the conflict parties. The Heckman probit models report that mediation as a form of conflict management is more likely in smaller countries. This indicates that the international community is able to "convince" internationally feeble belligerents to accept a mediation attempt. The impact of GDP per capita goes in the same direction, but is not statistically significant. These results cast some shadow on the proclamation that mediation is entirely a voluntary process. 
Table 2 further shows in line with our theoretical expectations that the longer the disputants have fought, the greater is the chance that the warring parties rely on an outside party to help resolving them their dispute. In contrast to a conflict's duration, its intensity does not exert a systematic effect. Note that only one of the control variables, recurrence, exerts a systematic effect. The more often a dyad has experienced a conflict, the less likely it is that the warring parties will seek the help of a third-party.

Table 2

Determinants of Mediation Occurrence and Strategy (Heckman Probit Regressions)

\begin{tabular}{|c|c|c|}
\hline & (1) & 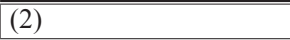 \\
\hline & \multicolumn{2}{|c|}{ Decisive mediation strategy } \\
\hline UN-led & $\begin{array}{c}-0.43 \\
(0.30)\end{array}$ & \\
\hline State-led & & $\begin{array}{c}0.15 \\
(0.29)\end{array}$ \\
\hline Multiparty mediation & $\begin{array}{c}0.11 \\
(0.23)\end{array}$ & $\begin{array}{c}0.24 \\
(0.27)\end{array}$ \\
\hline Mediator-initiated & $\begin{array}{c}0.26 \\
(0.22)\end{array}$ & $\begin{array}{c}0.28 \\
(0.22)\end{array}$ \\
\hline Previous mediation & $\begin{array}{l}1.37 * * * \\
(0.28)\end{array}$ & $\begin{array}{l}1.38 * * * \\
(0.29)\end{array}$ \\
\hline \multirow[t]{2}{*}{ Constant } & $\begin{array}{l}-0.89 * * * \\
(0.20)\end{array}$ & $\begin{array}{l}-1.06 * * * \\
(0.23)\end{array}$ \\
\hline & \multicolumn{2}{|c|}{ Mediation Occurrence } \\
\hline Population & $\begin{array}{c}-0.12 * * \\
(0.06)\end{array}$ & $\begin{array}{c}-0.12 * * \\
(0.06)\end{array}$ \\
\hline GDP per capita & $\begin{array}{c}-0.13 \\
(0.11) \\
\end{array}$ & $\begin{array}{c}-0.13 \\
(0.11)\end{array}$ \\
\hline War Duration & $\begin{array}{l}0.31 * * * \\
(0.05)\end{array}$ & $\begin{array}{l}0.31 * * * \\
(0.05)\end{array}$ \\
\hline Battle Deaths & $\begin{array}{c}0.05 \\
(0.12)\end{array}$ & $\begin{array}{c}0.05 \\
(0.12)\end{array}$ \\
\hline Military Alliance & $\begin{array}{c}-0.06 \\
(0.29)\end{array}$ & $\begin{array}{c}-0.06 \\
(0.29)\end{array}$ \\
\hline Polity & $\begin{array}{c}0.03 \\
(0.02)\end{array}$ & $\begin{array}{c}0.03 \\
(0.02)\end{array}$ \\
\hline Recurrence & $\begin{array}{c}-0.41^{*} \\
(0.22)\end{array}$ & $\begin{array}{c}-0.42 * \\
(0.21)\end{array}$ \\
\hline Internationalization & $\begin{array}{c}0.21 \\
(0.32)\end{array}$ & $\begin{array}{c}0.21 \\
(0.32)\end{array}$ \\
\hline Constant & $\begin{array}{c}-0.94 \\
(0.84)\end{array}$ & $\begin{array}{c}-0.95 \\
(0.84)\end{array}$ \\
\hline $\mathrm{N}$ & 581 & 581 \\
\hline $\mathrm{N}$ (censored) & 207 & 207 \\
\hline $\mathrm{N}$ (uncensored) & 374 & 374 \\
\hline Loglikelihood & -469.94 & -471.50 \\
\hline Rho & $\begin{array}{c}0.41 \\
(0.31)\end{array}$ & $\begin{array}{c}0.42 \\
(0.26)\end{array}$ \\
\hline $\mathrm{Chi}^{2}$ (Rho) & 1.66 & 1.96 \\
\hline
\end{tabular}

Standard errors in parentheses: $* \mathrm{p}<.1, * * \mathrm{p}<.05, * * * \mathrm{p}<.005$.

Source: Own calculations based on data collected. 
The analysis shows that characteristics of the conflict and the country suffering an internal war affect the chance of mediation. Mediation, in other words, does not occur randomly. Table 2 moreover shows in line with hypothesis 7 that the conflict history matters for the decision of the conflict manager to rely on a specific strategy. If there have been previous mediation attempts, the newly appointed conflict managers take this often as a carte blanche to employ a decisive mediation strategy. Although the signs for state-led and IGO-led mediations point in opposite directions, these influences are not statistically significant. We can therefore not say that states are per se more likely to adopt decisive strategies. Note, however, that especially the UN often steps in as conflict mediator when states have given up. The civil wars in El Salvador, Angola, and Mozambique where the United Nations were finally able to act as peace broker, illustrate the tendency that especially this central IGO often inherits the mandate to mediate in "orphaned conflicts" from state representatives or other conflict managers whose efforts have failed. We also do not find definitive confirmation for the hypothesis that mediator-initiated conflict management attempts are more likely to experience clear and decisive strategies. Note, however, that this influence is in some specification that we include in the web appendix statistically significant.

The negative influence of UN-led mediations in Model 1 in Table 2 further confirms our rational expectation hypothesis, according to which conflict parties try to select mediators with limited ambitions. The United Nations frequently prefers to consult with the conflicting parties, especially if the conflict takes place in powerful states, and refrains from using clear mediation strategies. States used directive strategies in 39 mediation attempts, procedural ones in 218, and communication facilitation in 56 conflicts. As expected, multi-party mediations do not rely on decisive strategies.

Under what conditions is mediation successful? The tests reported in Table 3 reveal that certain attributes of a mediator and the strategies used by the conflict manager can make a difference. The self-congratulatory statements that effective mediators often utter in the aftermath of a successful attempt to bring peace often hide that certain conflicts are easier to solve than other ones. Most importantly, the Heckman probit models reveal that a decisive strategy increases the chance of success. This finding corresponds with the literature on civil war termination that stresses the need for a more decisive third-party involvement than just getting the parties to the bargaining table (Walter, 2002). Additionally, while multiparty mediation is not linked to an increased chance that a mediator chooses a decisive strategy, multilateral third-party efforts render conflict management more effective. The Probit models reported in the Online Appendix show that UN-led and state-led mediations have a higher chance to be successful. However, these estimations do not take the selection effects into account.

Putting the evidence of the various tests together, we find considerable support for the argument that we must take both the structure of the conflict and the mediator identity into consideration in order to understand the interlinked phases of mediation. Hypotheses 1 and 2, according to which the population size of a conflict country and the intensity of conflict matter for mediation occurrence again received quite solid empirical backing. While war duration positively affects the probability that a conflict is mediated more populous countries are less likely to experience conflict management. 
Determinants of Mediation Occurrence and Success (Heckman Probit Regressions)

\begin{tabular}{|c|c|c|c|c|}
\hline & (1) & (2) & (3) & (4) \\
\hline & \multicolumn{4}{|c|}{ Mediation success } \\
\hline Decisive Strategy & $\begin{array}{l}0.36^{* *} \\
(0.18)\end{array}$ & $\begin{array}{l}0.36^{* *} \\
(0.18)\end{array}$ & & \\
\hline UN-led & & & $\begin{array}{c}0.44 \\
(0.31)\end{array}$ & \\
\hline State-led & & & & $\begin{array}{c}-0.08 \\
(0.19)\end{array}$ \\
\hline Multiparty mediation & & & $\begin{array}{l}0.34 * * \\
(0.15)\end{array}$ & $\begin{array}{c}0.25 \\
(0.17) \\
\end{array}$ \\
\hline Third-party territory & $\begin{array}{c}0.09 \\
(0.15)\end{array}$ & $\begin{array}{c}0.12 \\
(0.16)\end{array}$ & $\begin{array}{c}0.19 \\
(0.17)\end{array}$ & $\begin{array}{c}0.17 \\
(0.16)\end{array}$ \\
\hline State initiated mediation & & $\begin{array}{c}-0.38 * * \\
(0.15)\end{array}$ & $\begin{array}{c}-0.44 * * \\
(0.17)\end{array}$ & $\begin{array}{l}-0.44 * * * \\
(0.16)\end{array}$ \\
\hline IGO initiated mediation & & $\begin{array}{l}-0.17 \\
(0.23)\end{array}$ & $\begin{array}{c}-0.24 \\
(0.26)\end{array}$ & $\begin{array}{c}-0.19 \\
(0.25)\end{array}$ \\
\hline Previous mediation & $\begin{array}{c}-0.07 \\
(0.19)\end{array}$ & $\begin{array}{r}0.002 \\
(0.20)\end{array}$ & $\begin{array}{c}0.01 \\
(0.19)\end{array}$ & $\begin{array}{c}0.03 \\
(0.19)\end{array}$ \\
\hline \multirow[t]{2}{*}{ Constant } & $\begin{array}{c}-0.13 \\
(0.26)\end{array}$ & $\begin{array}{c}0.004 \\
(0.27)\end{array}$ & $\begin{array}{c}0.12 \\
(0.26)\end{array}$ & $\begin{array}{c}0.20 \\
(0.30)\end{array}$ \\
\hline & \multicolumn{4}{|c|}{ Mediation occurrence } \\
\hline Population & $\begin{array}{l}-0.13^{* *} \\
(0.05)\end{array}$ & $\begin{array}{l}-0.13 * * \\
(0.05)\end{array}$ & $\begin{array}{l}-0.13 * * \\
(0.05)\end{array}$ & $\begin{array}{l}-0.13 * * \\
(0.05)\end{array}$ \\
\hline GDP per capita & $\begin{array}{c}-0.15 \\
(0.11) \\
\end{array}$ & $\begin{array}{c}-0.15 \\
(0.11) \\
\end{array}$ & $\begin{array}{c}-0.15 \\
(0.11) \\
\end{array}$ & $\begin{array}{c}-0.15 \\
(0.11) \\
\end{array}$ \\
\hline War Duration & $\begin{array}{l}0.29 * * * \\
(0.05)\end{array}$ & $\begin{array}{l}0.29 * * * \\
(0.05)\end{array}$ & $\begin{array}{l}0.29 * * * \\
(0.05)\end{array}$ & $\begin{array}{l}0.29 * * * \\
(0.05)\end{array}$ \\
\hline Battle Deaths & $\begin{array}{c}0.06 \\
(0.11)\end{array}$ & $\begin{array}{c}0.06 \\
(0.11)\end{array}$ & $\begin{array}{c}0.06 \\
(0.11) \\
\end{array}$ & $\begin{array}{c}0.06 \\
(0.11) \\
\end{array}$ \\
\hline Military Alliance & $\begin{array}{c}-0.002 \\
(0.30)\end{array}$ & $\begin{array}{l}-0.03 \\
(0.32)\end{array}$ & $\begin{array}{l}-0.03 \\
(0.32)\end{array}$ & $\begin{array}{l}-0.03 \\
(0.32)\end{array}$ \\
\hline Polity & $\begin{array}{c}0.03 \\
(0.02)\end{array}$ & $\begin{array}{c}0.03 \\
(0.02)\end{array}$ & $\begin{array}{c}0.03 \\
(0.02)\end{array}$ & $\begin{array}{c}0.02 \\
(0.02)\end{array}$ \\
\hline Recurrence & $\begin{array}{c}-0.25 \\
(0.22)\end{array}$ & $\begin{array}{c}-0.26 \\
(0.22)\end{array}$ & $\begin{array}{l}-0.27 \\
(0.22)\end{array}$ & $\begin{array}{c}-0.27 \\
(0.22)\end{array}$ \\
\hline Internationalization & $\begin{array}{c}0.21 \\
(0.36)\end{array}$ & $\begin{array}{c}0.21 \\
(0.36)\end{array}$ & $\begin{array}{c}0.19 \\
(0.38)\end{array}$ & $\begin{array}{c}0.21 \\
(0.37)\end{array}$ \\
\hline Constant & $\begin{array}{c}-0.84 \\
(0.76)\end{array}$ & $\begin{array}{c}-0.85 \\
(0.76)\end{array}$ & $\begin{array}{c}-0.83 \\
(0.77)\end{array}$ & $\begin{array}{c}-0.84 \\
(0.76)\end{array}$ \\
\hline $\mathrm{N}$ & 488 & 488 & 488 & 488 \\
\hline $\mathrm{N}$ (censored) & 207 & 207 & 207 & 207 \\
\hline $\mathrm{N}$ (uncensored) & 281 & 281 & 281 & 281 \\
\hline Loglikelihood & -446.23 & -443.08 & -442.26 & -443.57 \\
\hline Rho & $\begin{array}{c}-0.48 \\
(0.21)\end{array}$ & $\begin{array}{c}-0.52 \\
(0.20)\end{array}$ & $\begin{array}{c}-0.50 \\
(0.21)\end{array}$ & $\begin{array}{c}-0.50 \\
(0.20)\end{array}$ \\
\hline $\mathrm{Chi}^{2}$ (Rho) & $3.81 *$ & $4.56^{* *}$ & $3.77 *$ & $4.20 * *$ \\
\hline
\end{tabular}

Standard errors in parentheses: $* \mathrm{p}<.1, * * \mathrm{p}<.05, * * * \mathrm{p}<.005$.

Source: Own calculations based on data collected.

Power, therefore, largely allows war-torn countries to shield themselves against conflict management. If warring parties decide nevertheless on mediation, they try to choose 
mediators who will most likely see their efforts thwarted in the end. Yet, the warring parties often underestimate in line with our theoretical expectation the determination of the conflict manager. Our empirical tests provide in this vein ample evidence in favor of the expectation that the selection of forceful strategies makes a difference (H3). A decisive mediation strategy increases the chance of success even when we control for the step-wise nature of mediation in line with our theoretical framework. A telling example of a mediator who adopted a surprisingly forceful conflict management attempt is the behavior of the African Union (AU), formerly known as the Organization of African Unity (OAU) in the civil conflict in Comoros. As a reaction to the worsening secessionist crisis in Anjouan and the failure of previous mediation efforts, the AU imposed economic sanctions and threatened military action against President Mohamad Bacar's regime on the island Anjouan in 2002. The result of the outside pressure was a transition of entire the archipelago island nation to a confederation and a series of elections. However, when President Bacar refused to leave office in 2008, the AU was forced to intervene militarily to restore public order.

Moreover, we find support for the assumption that indicates it is better for a mediation attempt if it is not initiated by the mediator, be it a state or intergovernmental organization, but rather by the parties engaged in the dispute themselves (H4). The aforementioned Indian interventions in Sri Lanka were, according to Keethaponcalan (2001: 92), further doomed by the lack of "a genuine interest in making peace."

We also find in line with our theoretical framework that mediations which are led by the multilateral team have an increased chance to be successful (H5). Successful multilateral mediation occurred in El Salvador (UN, Catholic Church, and the U.S.) at the beginning of 1990s, in Colombia from 1999 to 2002 (UN, Catholic Church, Cuba, France, and Switzerland) or the Central African Republic from 2001 to 2003 (UN, OAU, Bishop Paulin Pomodimo). However, there is no systematic effect of where the mediation attempt takes place (H6). Examples of successful mediations that took place on the territory of the mediator are the peace talks led by U.S. President Clinton to end Israeli-Palestinian conflict. Although these mediation attempts led to the Oslo Accords I and II in 1993 and 1995, the treaties did not stop the two sides to resume the fighting in the second half of the decade. This might indicate that moving the negotiations to a country outside of the conflict zone is seldom sufficient in bringing peace, but it also might be that such cases are the especially difficult ones to mediate successfully. Conflict managers finally who intervene in previously mediated conflicts are not more likely to convince the disputants to sign a peace agreement (H7). The Second Sudanese Civil War (1983-2005) for instance saw nine mediation attempts before a Comprehensive Peace Agreement was signed, and the conflicts in Cambodia, Azerbaijan, and Sri Lanka also only ended after successions of mediators had returned home empty-handed.

$$
* * *
$$

The success of third parties in their endeavor to negotiate a peaceful settlement to a militarized conflict can be explained in terms of a mixture of different factors, some of them relating to the conflict itself, some relate to the parties that engage in conflict, 
and some relate to individual attributes of a mediator. Mediation is, in other words, not just an exogenous input, unaffected by the reality of a conflict. Nor is it a mechanism solely dependent on mediator characteristics, as we were led to think by the memoirs and reminiscences of successful conflict managers. Mediation both affects and reflects, to some extent, the conflict environment in which it takes place. In this article, we have advanced a theoretical framework inspired by the bargaining theory of war to combine the structural and the actor-centric perspective. We particularly argue that mediation characteristics are only able to increase the chance of a peaceful settlement if at least one of the belligerents underestimates the chance that the chosen mediator employs a decisive conflict management strategy. Mediators can, to put it differently, make a difference if the conflict parties them did not anticipate a forceful intervention when selecting the third party or when they are so war-weary after some unsuccessful mediations that they accept the intrusive moves by the third party.

The empirical evaluation supports this double conjecture that it is important not only who mediates, but under certain conditions also how this conflict manager mediates. Hence, a decisive mediation strategy matters even if we control for the tendency that only wars with a particular profile experience this form of conflict management. If the conflict parties had perfectly predicted what strategy the selected mediator would employ, we could explain the effectiveness of a mediation attempt solely through attributes of the conflict and the mediator.

The voluntary nature of conflict management has its limits through the temptation of both states and IGOs to press a mediation offer on the belligerents. However, as our theoretical framework suggests, such attempts are less successful (state initiated mediations) or as successful (IGO initiated mediations) as completely voluntary conflict management attempts. We also find in some specifications that multiparty mediations are more effective, but we could not establish that either state- or UNled mediations make a difference. The article also provides evidence in line with our theoretical expectation that the structure of the conflict only self-selects certain armed conflicts into the usage of mediation. We particularly find in line with the structural perspective that the longer a dispute lasts, the more likely it is that mediation is adopted as a conflict management tool. However, the intensity of a conflicts in terms of battle deaths are not necessarily always more likely to be mediated than less violent ones.

Our paper also contributes to the recent literature on sequencing (Heldt, 2009). We particularly pay attention to the history of mediation within conflicts that experience repeated conflict management attempts. Disputants who move back to mediation are more inclined to move to a negotiated settlement because of the growing costs of conflict. Yet, they do so particularly if a directive strategy is applied.

We acknowledge that our dichotomous categorization of mediation strategies does not give full justice to the plethora of sophisticated tactics that conflict managers use. The comparative evaluation of mediation could therefore profit from attempts to code the incentives and disincentives mediators possess and employ in a more nuanced way. Comprehensive data might not only help the research community, but could also provide policy makers with benchmarks of what kind of strategy works in what context. 


\section{BIBLIOGRAPHY}

Amoo S. G., Zartman W. I. (1992), Mediation by Regional Organizations: The Organization of African Unity $(O A U)$ in Chad, in: Mediation in international relations, (eds.) J. Bercovitch, J. Z. Rubin, Macmillan Press Limited, London, pp. 131-148.

Balch-Lindsay D., Enterline A. J. (2000), Killing time: The world politics of civil war duration, 1820-1992, "International Studies Quarterly", Vol. 44, No. 4, pp. 615-642.

Beardsley K. (2011), The Mediation Dilemma, Cornell University Press, Ithaca.

Beardsley K. C. (2008), Agreement without peace? international mediation and time inconsistency problems, "American Journal of Political Science", Vol. 52, No. 4, pp. 723-740.

Beardsley K. C., Quinn D. M., Biswas B., Wilkenfeld J. (2006), Mediation style and crisis outcomes, "Journal of Conflict Resolution", Vol. 50, No. 1, pp. 58-86.

Beardsley K., Michael G. (2009), Disaggregating the incentives of conflict management: An introduction, "International Interactions", Vol. 35 (3), pp. 243-248.

Beber B. (2012), International Mediation, Selection Effects, and the Question of Bias, "Conflict Management and Peace Science", No. 29, pp. 397-424.

Bercovitch J. (1986), International Mediation: A Study of Incidence, Strategies and Conditions of Successful Outcomes, "Cooperation and Conflict”, Vol. 21, pp. 155-168.

Bercovitch J. (1996), Understanding Mediation's Role in Preventative Diplomacy, "Negotiation Journal", Vol. 12, No. 3, pp. 241-258.

Bercovitch J. (2011), Theory and Practice of International Mediation: Selected Essays, Routledge.

Bercovitch J., Anagnoson J. T., Wille D. L. (1991), Some conceptual issues and empirical trends in the study of successful mediation in international relations, "Journal of Peace Research", Vol. 28, No. 1, pp. 7-17.

Bercovitch J., DeRouen K. R. (2004), Mediation in internationalized ethnic conflicts: Assessing the determinants of a successful process, “Armed Forces \& Society” Vol. 30, No. 2, pp. 147-170.

Bercovitch J., DeRouen K. R. (2005), Managing ethnic civil wars: Assessing the determinants of successful mediation, "Civil Wars", Vol. 7, No. 1, pp. 98-116.

Bercovitch J., Fretter J. (2007), Studying International Mediation: Developing Data Sets on Mediation, Looking for Patterns, and Searching for Answers, "International Negotiation", Vol. 12, No. 2, pp. 145-173.

Bercovitch J., Gartner S. S. (2006), Is there method in the madness of mediation? Some lessons for mediators from quantitative studies of mediation, "International Interactions", Vol. 32, No. 4, pp. 329-354.

Bercovitch J., Houston A. (1993), Influence of mediator characteristics and behavior on the success of mediation in international relations, "International Journal of Conflict Management" Vol. 4, No. 4, pp. 297-321.

Bercovitch J., Houston A. (1996), The study of international mediation: Theoretical issues and empirical evidence, in: Resolving international conflicts. the theory and practice of mediation, (ed.) J. Bercovitch, Lynne, Boulder, pp. 11-38.

Bercovitch J., Houston A. (2000), Why do they do it like this? An analysis of the factors influencing mediation behavior in international conflicts, "Journal of Conflict Resolution", Vol. 44 (2), pp. 170-202.

Bercovitch J., Jackson R. (2001), Negotiation or Mediation? An Exploration Factors Affecting the Choice of Conflict Management in International Conflict, "Negotiation Journal, Vol. 17, No. 1, pp. 59-77. 
Bercovitch J., Langley J. (1993), The nature of the dispute and the effectiveness of international mediation, "Journal of Conflict Resolution", Vol. 37 (4), pp. 670-691.

Bercovitch J., Schneider G. (2000), Who mediates? the political economy of international conflict management, "Journal of Peace Research", Vol. 37, No. 2, pp. 145-165.

Bercovitch J., Simpson L. (2010), International mediation and the question of failed peace agreements: Improving conflict management and implementation, "Peace \& Change", Vol. 35, No. 1, pp. 68-103.

Böhmelt T. (2010), The effectiveness of tracks of diplomacy strategies in third-party interventions, "Journal of Peace Research", Vol. 47, No. 2, pp. 167-178.

Böhmelt T. (2015), The spatial contagion of international mediation, "Conflict Management and Peace Science", Vol. 32 (1), pp. 108-127.

Böhmelt T. (2016), The importance of conflict characteristics for the diffusion of international mediation, "Journal of Peace Research", Vol. 53 (3), pp. 378-391.

Burton J. W. (1969), Conflict and communication: The use of controlled communication in international relations, MacMillan, London.

Clayton G. (2015), Oil, relative strength and civil war mediation, in: Cooperation and Conflict (in press), doi: 10. 1177/0010836715610596.

Crescenzi M., Kadera K., McLaughlin S. M., Thyne C. (2011), A supply side theory of mediation, "International Studies Quarterly", Vol. 55 (4), pp. 1069-1094.

Crocker C. A., Hampson F. O., Aall P. (eds.) (1999), Herding cats: Multiparty mediation in a complex world, United States Institute of Peace Press, Washington, D.C.

Danner M. (1997), Clinton, the UN, and the Bosnian Disaster, "The New York Review of Books", December 18.

DeRouen K. (2003), The role of the UN in international crisis termination, 1945-1994, "Defense and Peace Economics" Vol. 14, No. 4, pp. 251-260.

DeRouen K. R., Bercovitch J. (2008), Enduring internal rivalries: A new framework for the study of civil war, "Journal of Peace Research", Vol. 45, No. 1, pp. 55-74.

DeRouen K. R., Bercovitch J., Pospieszna P. (2011), Introducing the Civil Wars Mediation (CWM) Dataset, "Journal of Peace Research", Vol. 48, No. 5, pp. 663-672.

DeRouen K., Bercovitch J., Wei J. (2009), Duration of peace and recurring civil wars in Southeast Asia and the Pacific, "Civil Wars", Vol. 11, No. 2, pp. 103-120.

Dixon W. J. (1993), Democracy and the Management of International Conflict, "Journal of Conflict Resolution", Vol. 37, No. 1, pp. 42-68.

Dixon W. J. (1994), Democracy and the Peaceful Settlement of International Conflict, "American Political Science Review", Vol. 88, No. 1, pp. 14-32.

Doyle M. W., Sambanis N. (2000), International peace building: A theoretical and quantitative analysis, "The American Political Science Review”, Vol. 94, No. 4, pp. 779-801.

Elgstrom O. (1994), National Culture and International Negotiation, "Cooperation and Conflict", Vol. 29, No. 3, pp. 289-301.

Frazier D. V., Dixon W. J. (2006), Third-party intermediaries and negotiated settlements, 1946-2000, "International Interactions", Vol. 32, No. 4, pp. 385-408.

Gartner S. S. (2011), Signs of Trouble: Regional Organization Mediation and Civil War Agreement Durability, "The Journal of Politics”, Vol. 73, No. 2, pp. 380-390.

Greig J. M., Diehl P. F. (2006), Softening up: Making conflicts more amenable to diplomacy, "International Interactions", Vol. 32, No. 4, pp. 355-384. 
Greig J. M, Regan P. M. (2008), When Do They Say Yes? An Analysis of the Willingness to Offer and Accept Mediation in Civil Wars, "International Studies Quarterly", Vol. 52, No. 4, pp. 759-781.

Greig J. M. (2001), Moments of Opportunity: Recognizing Conditions of Ripeness for International Mediation between Enduring Rivals, "Journal of Conflict Resolution", Vol. 45, No. 6, pp. 691-718.

Hegre H., Ellingsen T., Gates S., Gleditsch N. P. (2001), Towards a democratic civil peace? Democracy, political change, and civil war, 1816-1992, "American Political Science Review", Vol. 95, No. 10, pp. 33-48.

Heldt B. (2009), Sequencing of Peacemaking in Emerging Conflicts, in: War and Peace in Transition: Chagning Roles of External Actors, (eds.) K. Aggestam, A. Björkdahl, Nordic Academic Press.

Hensel P. R. (2001), Contentious Issues and World Politics: The Management of Territorial Claims in the Americas, 1816-1992, "International Studies Quarterly", Vol. 45, No. 1, pp. 81-109.

Jarstad A. K., Sisk T. D. (eds.) (2008), From War to Democracy: Dilemmas of Peacebuilding, Cambridge University Press, Cambridge.

Jonah J. O. (1992), The United Nations and International Conflict: The Military Talks at Kilometer Marker-101, in: Mediation in International Relations, (eds.) J. Bercovitch, J. Z. Rubin, Macmillan Press Limited, London, pp. 176-205.

Kathman J. (2011), Civil war diffusion and regional motivations for intervention, "Journal of Conflict Resolution”, Vol. 55, No. 6, pp. 847-876.

Keethaponcalan S. I. (2001), Mediation Dilemmas: Resolving the Ethnic Conflict in Sri Lanka, "Pakistan Horizon", Vol. 54, No. 2, pp. 79-98.

Kleiboer M. (1996), Understanding success and failure of international mediation, "Journal of Conflict Resolution", Vol. 40, No. 2, pp. 360-389.

Kuypers J. A. (1997), Presidential Crisis Rhetoric and the Press in the Post-Cold War World, CT: Praeger, Westport.

Kydd A. (2003), Which Side Are You On? Bias, Credibility, and Mediation, “American Journal of Political Science", Vol. 47 (4), pp. 597-611.

Maoz Z., Terris L. (2009), Credibility and Strategy in International Mediation, "International Interactions", Vol. 32, No. 4, pp. 409-440.

Mason T. D., Fett P. J. (1996), How Civil Wars End: A Rational Choice Approach, "Journal of Conflict Resolution”, Vol. 40, No. 4, pp. 546-568.

Mitchell S. M., Hensel P. R. (2007), International Institutions and Compliance with Agreements, "American Journal of Political Science", Vol. 51, No. 4, pp. 721-737.

Powell R. (2012), Persistent Fighting and Shifting Power, "American Journal of Political Science", Vol. 56 (3), pp. 620-637.

Quinn D., Wilkenfeld J., Eralp P., Asal V., Mclauchlin T. (2013), Crisis managers but not conflict resolvers: Mediating ethnic intrastate conflict in Africa, "Conflict Management and Peace Science", Vol. 30 (4), pp. 387-440.

Rauchhaus R. (2006), Asymmetric information, mediation and conflict management, "World Politics", Vol. 58, No. 2, pp. 207-241.

Regan P. M., Aydin A. (2006), Diplomacy and Other Forms of Intervention in Civil Wars, "Journal of Conflict Resolution", Vol. 50, No. 5, pp. 736-756.

Regan P., Stam A. (2000), In the nick of time: Conflict management, mediation timing, and the duration of interstate disputes, "International Studies Quarterly”, Vol. 44 (2), pp. 239-260. 
Rubin J. Z. (1980), Experimental research on third-party intervention in conflict, "Psychological Bulletin", Vol. 87 (2), pp. 379-391.

Slim R. M. (1992), Small state mediation in international relations: The Algerian mediation of the Iranian hostage crisis, in: Mediation in international relations. multiple approaches to conflict management, (eds.) J. Bercovitch, J. Z. Rubin, St. Martin Press, New York, pp. 206-231.

Svensson I. (2007), Mediation with Muscles or Minds? Exploring Power Mediators and Pure mediators in Civil Wars, "International Negotiation", Vol. 12, No. 2, pp. 229-248.

Svensson I. (2009), Guaranteeing Peace: the Credibility of Third-Party Mediators in Civil Wars, in: International Conflict Mediation: New Approaches and Findings, (eds.) J. Bercovitch, S. Sigmund Gartner, pp. 115-134.

Terris L. G., Maoz Z. (2005), Rational Mediation: A Theory and a Test, "Journal of Peace Research", Vol. 42, No. 5, pp. 563-584.

Touval S. (1994), Why the UN fails, "Foreign Affairs", Vol. 73, No. 5, pp. 44-57.

Wagner R. H. (2000), Bargaining and war, “American Journal of Political Science”, Vol. 44, No. 3 , pp. 469-484.

Wall J. A., Stark J. B. Rhetta, Standifer L. (2001), Mediation: A current review and theory development, "Journal of Conflict Resolution", Vol. 45, No. 3, pp. 370-391.

Wallensteen P., Svensson I. (2014), Talking peace: International mediation in armed conflicts, "Journal of Peace Research", Vol. 51, No. 2, pp. 315-327.

Walter B. (2002), Committing to peace: The successful settlement of civil wars, Princeton University Press, Princeton.

Wilkenfeld J., Young K., Asal V., Quinn D. M. (2003), Mediating international crises: Crossnational and experimental perspectives, "Journal of Conflict Resolution", Vol. 47, No. 3, pp. 279-301.

Young O. (1967), Intermediaries: Third Parties in International Crises, Princeton University Press, Princeton.

Zartman I. W. (1989), Ripe for Resolution: Conflict and Intervention in Africa, Oxford University Press, New York.

Zartman I. W., Touval S. (1996), International mediation in the post-cold war era, in: Managing global chaos, (eds.) C. A. Crocker, F. O. Hampson (with P. Aall), United States Institute of Peace, Washington, DC, pp. 445-461.

\begin{abstract}
The literature on conflict management offers two explanations of why the effectiveness of third parties to settle militarized disputes differs. The structural research tradition focuses on conflict characteristics, while the individualist approaches highlight the background, skills and power of a mediator, as well as the mediation strategy. This article reconciles these two approaches, and examines especially the effectiveness of mediation strategies. Accounting for the selection of mediation and the success of mediation attempts, we use the CWM 1945-2004 dataset. The analysis demonstrates that mediators who were able to pursue a determined strategy face a higher chance of success.
\end{abstract}

Keywords: civil wars, civil war mediation, conflict resolution, mediation strategies 


\title{
RODZAJ KONFLIKTU CZY UMIEJĘTNOŚCI MEDIATORA? \\ W POSZUKIWANIU CZYNNIKÓW WPLYWAJĄCYCH NA SUKCES \\ ROZWIĄZYWANIA KONFLIKTÓW WEWNĘTRZNYCH
}

\begin{abstract}
STRESZCZENIE
Literatura przedmiotu dotycząca działań mających na celu zapobieganie konfliktom oferuje dwa wyjaśnienia dlaczego ocena wpływu stron trzecich w zakresie zarządzania kryzysowego i rozwiązywania konfliktów poprzez mediacje tak bardzo różni się. Pierwsze wyjaśnienie uzależnia pozytywny wynik mediacji w wojnach domowych od specyficznych cech konfliktu, natomiast drugie wyjaśnienie od umiejętności i doświadczenia mediatora oraz od strategii mediacji zastosowanych w procesie rozwiązywania konfliktu pomiędzy stronami. Celem badań jest ustalenie jakie czynniki w przedstawionych podejściach mają decydujący wpływ na to, że niektóre wysiłki mediatorów kończą się sukcesem a niektóre nie. Badania zostały przeprowadzone na próbie 581 mediacji w wojnach domowych w latach 1945-2004 i potwierdziły nasze założenia dotyczące strategii mediacji. Analiza pokazuje, że mediatorzy, którzy przejmują inicjatywę i sugerują rozwiązania (directive mediation strategies), odnoszą większy sukces w rozwiązaniu konfliktu niż mediatorzy którzy stosują mediacje facylitatywne.
\end{abstract}

Słowa kluczowe: wojny domowe, mediacje, rozwiązywanie konfliktów, rodzaje mediacji 